\title{
Geotechnology as support for the management of conservation units in Brazil's Pantanal
}

\section{Geotecnologias como suporte ao manejo de unidades de conservação do Pantanal, Brasil}

\author{
Ciomara de Souza Miranda!', Anny Keli Aparecida Alves Cândido"l, Camila Leonardo Mioto'II, \\ Normandes Matos da Silva"l, Antônio Conceição Paranhos Filho"'I, Arnildo Pott"II \\ Instituto Federal de Mato Grosso do Sul. Aquidauana, Mato Grosso do Sul, Brasil \\ "Universidade Federal do Mato Grosso. Rondonópolis, Mato Grosso, Brasil \\ "'Universidade Federal do Mato Grosso do Sul. Campo Grande, Mato Grosso do Sul, Brasil
}

\begin{abstract}
The aim of this paper is to study temporal variations in vegetation indices as a tool for monitoring the integral protection conservation units (parks, reserves, and ecological stations) in the Brazilian Pantanal, giving support to environmental management actions in these areas. The study was carried out in five conservation units. Evaluated data, beside the Normalized Difference Vegetation Index (NDVI), included information on wildfires and deforestation. Analyses showed that the Taiamã Ecological Station, the Pantanal Matogrossense National Park, and the Encontro das Aguas State Park presented high vegetation indices, showing their effectiveness as areas of environmental protection. Although this latter state park presented one fire hotspot in 2015, there was significant improvement in this park. The Guirá State Park and the Pantanal of Rio Negro State Park presented relatively low NDVI values when compared with other analysed areas. The aggravating factor was that in the Rio Negro park 36 fire hotspots occurred in 2007, demonstrating the need for more vigorous monitoring and management of this protected area.
\end{abstract}

Keywords: Landsat. NDVI. Remote sensing. Surface reflectance.

Resumo: A proposta desta pesquisa é estudar a variação multitemporal do índice de vegetação como ferramenta de subsídio ao monitoramento das unidades de conservação (UC) de proteção integral no Pantanal, dando suporte à consolidação de ações de gestão ambiental dessas áreas. O estudo foi realizado em cinco UC, situadas na porção brasileira do Pantanal. Os dados foram avaliados por meio do Índice de Vegetação da Diferença Normalizada (IVDN), além de terem sido observadas informações de foco de calor e supressão vegetal nas UC. Essas análises mostraram que a Estação Ecológica Taiamãa o Parque Nacional do Pantanal Mato-Grossense e o Parque Estadual Encontro das Águas apresentaram alto índice de vegetação na totalidade dessas áreas, mostrando a efetividade desses locais como área de proteção ambiental. Apesar de esta última ter apresentado um foco de incêndio em 2015, não houve alteração significativa nesta UC. Já o Parque Estadual do Guirá e o Parque Estadual do Pantanal do Rio Negro apresentaram IVDN relativamente baixo quando comparados com as demais UC analisadas, com o agravante de que na UC do Rio Negro, em 2007, aconteceram 36 focos de incêndios, o que demonstra a necessidade de ações de maior austeridade no monitoramento e no controle dessa área de proteção.

Palavras-chave: Landsat. IVDN. Sensoriamento remoto. Reflectância da superfície.

MIRANDA, C. S., A. K. A. A. CÂNDIDO, C. L. MIOTO, N. M. SILVA, A. C. PARANHOS FILHO \& A. POTT, 2017. Geotechnology as support for the management of conservation units in Brazil's Pantanal. Boletim do Museu Paraense Emílio Goeldi. Ciências Naturais 12(2): 255-264.

Autora para correspondência: Ciomara de Souza Miranda. Instituto Federal do Mato Grosso do Sul. Rua José Tadão Arima. Aquidauana, MS, Brasil. CEP 79200-000 (ciomara.miranda@gmail.com).

Recebido em 29/03/2017

Aprovado em 13/09/2017

Responsabilidade editorial: Fernando da Silva Carvalho Filho

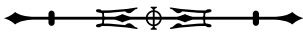




\section{INTRODUCTION}

The creation and maintenance of parks, reserves, and ecological stations, collectively termed conservation units (unidades de conservação), represent one of the main management tools for protecting natural areas in Brazil, following the National System of Conservation Units (Sistema Nacional de Unidades de Conservação - SNUC; Law 6.985) (Brasil, 2000). Aiming at the conservation of ecosystems and biodiversity in the face of anthropic pressures, conservation units come to the forefront as a manifestation of conservation efforts (Nelson \& Chomitz, 2011). It is considered that the creation and consolidation of a system of protected areas, including conservation units, legal reserves, and areas of permanent preservation, will constitute an effective nature conservation action, as one of the main strategies of Brazilian environmental policy.

The Pantanal wetlands attract worldwide environmental interest and have an outstanding position for their unique characteristics. However, only $4.4 \%$ of the region is protected by conservation units, of which 2.9\% correspond to full protection areas and 1.5\% to sustainable use areas (MMA, 2014). Aproximately $36 \%$ of the area of the Brazilian Pantanal is located in the state of Mato Grosso, and of this portion $7.37 \%$ are full protection areas, while of the $64 \%$ of the area in Mato Grosso do Sul only $0.87 \%$ are occupied by conservation units. This is an important fact for advocates of new full protection areas in the Pantanal, mainly in Mato Grosso do Sul.

Areas of environmental protection can be created based on past studies, but the field studies can reveal whether the area does in fact fulfill its function in the conservation of local biodiversity, turning necessary the creation of tools to evaluate the effectiveness of management actions (Timko \& Innes, 2009). Willis (2015) summarized the main remote sensing techniques used to monitor protected areas in the USA, and pointed out the importance of monitoring programs utilizing geotechnology to study ecological systems and thereby quantify landscape changes.
Nagendra et al. (2013) highlighted that remote sensing plays a key role in the characterization and mapping of habitats within and around protected areas, contributing to their effective management.

Remote sensing techniques are successful as monitoring strategies for protected areas (Silva et al., 2009; Saito et al., 2016). However, in some cases there is a scarcity of human resources with the ability in interpretation and analyses of remote sensing data, implying the need to train additional specialists (Nagendra et al., 2013; Willis, 2015).

The Normalized Difference Vegetation Index (NDVI) is widely utilized to assess several biophysical parameters, such as green cover, biomass, fraction of the photosyntetically active radiation (Huete et al., 2002), and phenological variations (Prabakaran et al., 2013). It is a classical tool for vegetation mapping utilizing remote sensing, since it works with information of refletance in the red and near-infrared region of the spectrum (Xie et al., 2008).

This study aims to apply a multitemporal analysis of the vegetation index in Pantanal protected areas and their buffer zones in order to measure environmental parameters and verify possible human impacts, thus supporting environmental management actions in these areas.

\section{MATERIAL AND METHODS}

\section{STUDY AREA}

The study area is composed of the full protection reserves within the Brazilian Pantanal wetlands. The five studied areas are: the Pantanal Matogrossense National Park, the Guirá State Park, Encontro das Águas State Park, the Taiamã Ecological Station, and the Pantanal of Rio Negro State Park (Figure 1, Table 1), as well as a $3 \mathrm{~km}$ wide buffer zone as defined by Resolution 428 of the National Council for the Environment (Conselho Nacional do Meio Ambiente - CONAMA) (Brasil, 2010), in order to verify possible anthropic impacts in these buffer zones.

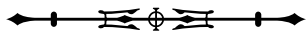




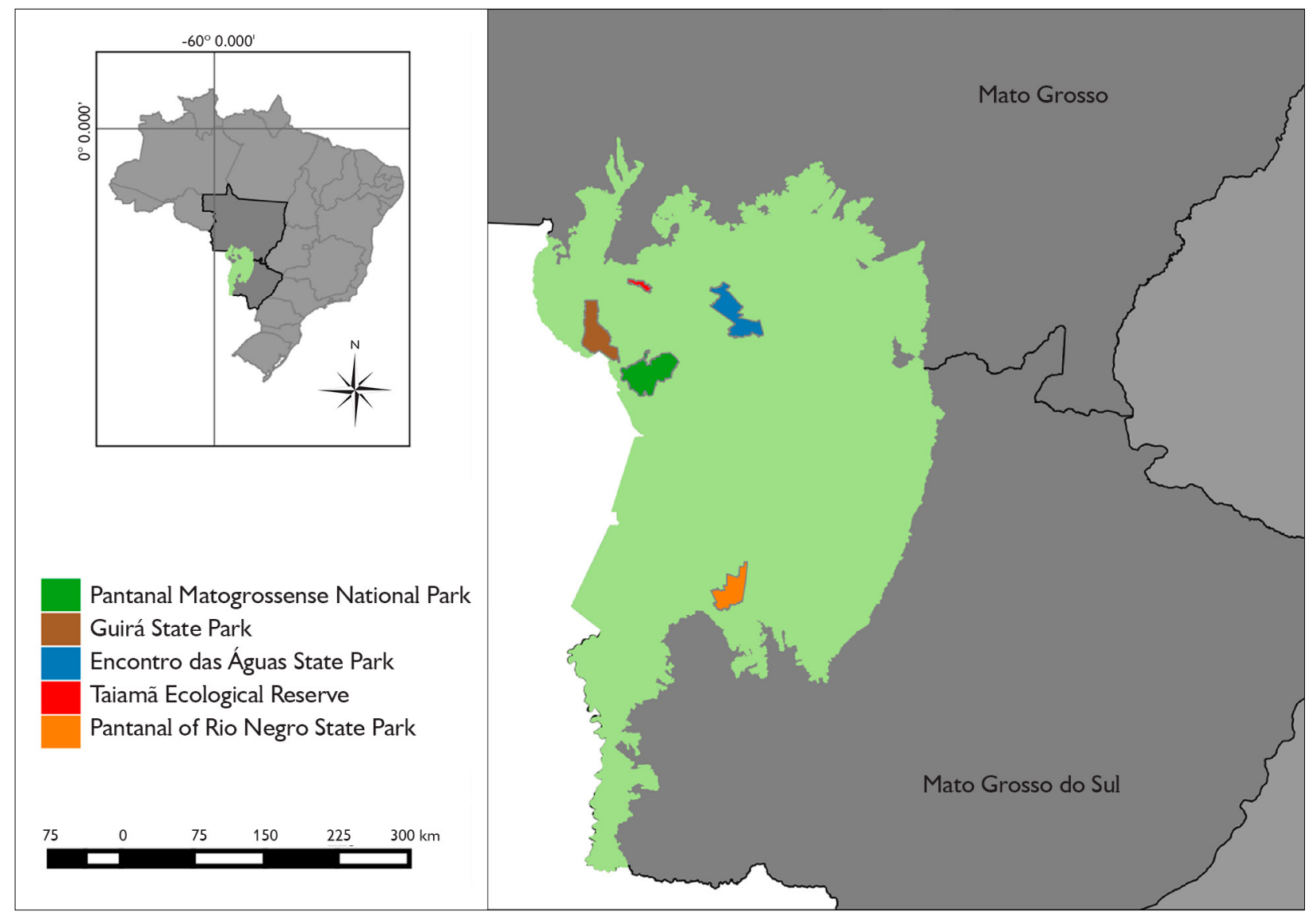

Figure 1. Location of the Pantanal wetlands (light green) in Brazil (small map) and in Mato Grosso and Mato Grosso do Sul (large map), and of full protection conservation units (other colors) in the Pantanal.

Table 1. Area, year of creation, and jurisdiction of full protection conservation units in the Brazilian Pantanal.

\begin{tabular}{c|c|c|c}
\hline Conservation unit & $\begin{array}{c}\text { Area } \\
\left(\mathrm{km}^{2}\right)\end{array}$ & $\begin{array}{c}\text { Year of } \\
\text { creation }\end{array}$ & Jurisdiction \\
\hline $\begin{array}{c}\text { Pantanal Matogrossense } \\
\text { National Park }\end{array}$ & 1359.23 & 1981 & Federal \\
\hline $\begin{array}{c}\text { Encontro das Águas } \\
\text { State Park }\end{array}$ & 1081.29 & 2004 & State \\
\hline $\begin{array}{c}\text { Guirá State Park } \\
\text { Pantanal of Rio Negro } \\
\text { State Park }\end{array}$ & 1046.62 & 2002 & State \\
\hline $\begin{array}{c}\text { Taiamã Ecological } \\
\text { Station }\end{array}$ & 115.55 & $\begin{array}{c}2000 \\
\text { (expansion } \\
\text { in 2009) }\end{array}$ & Federal \\
\hline
\end{tabular}

\section{SURFACE REFLECTANCE DATA FROM}

\section{LANDSAT IMAGES}

NASA's Goddard Space Flight Center (GSFC) and the University of Maryland (Masek et al., 2006) developed specialized software named Landsat Ecosystem Disturbance Adaptive Processing System (LEDAPS), for generating data on surface reflectance from images and other Landsat 4-7 information. This software applies the same routine of atmospheric correction used in products at Level-1 from Resolution Imaging Spectroradiometer (MODIS) images and utilizes the model of radioactive transference named 6s (Second Simulation of Satellite Signal in the Solar Spectrum, simulation of the second satellite signal in the solar spectrum) (Vermote et al., 1997)

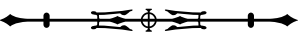


to generate data on reflectance of the top of atmosphere (TOA), surface reflectance, shine temperature, and cloud masks, cloud shades, adjacent clouds, land, and water. Global data on steam, ozone, geopotential height, aerosol optical thickness, and digital elevation are received from the Landsat data to apply the model 6s (USGS, 2013). Different from the algorithm used to process the LEDAPS referring to the reflectance of Landsat 4-7 images, the information of surface reflectance of Landsat 8 is generated by the software L8SR, openly available at the Earth Resources Observation and Science (EROS) (USGS, 2016).

The surface reflectance of LEDAPS from Landsat 5 for 2000, 2003, 2007 and 2011, selecting the months of August and September as the dry season in the region, and the surface reflectance of L8SR for the Landsat 8 scenes with the same orbits and points aforementioned for 2015, selecting the month of August to cover each conservation unit and its buffer zone, were obtained from the United States Geological Survey website Earth Explorer (USGS, s. d.). We utilized the following images (orbit and point): 226/74 and 226/73 for Pantanal of Rio Negro State Park in MS, 226/72 and 227/72 for Encontro das Águas State Park, and $227 / 72$ for the other conservation units, the dates of images being shown in Table 2 .

\section{NORMALIZED DIFFERENCE VEGETATION}

\section{INDEX}

The Normalized Difference Vegetation Index (NDVI) proposed by Rouse et al. (1973) is calculated as the difference of reflectance of the vegetation in the bands of near-infrared (NIR) and red (R). The difference is normalized by the division of NIR and R bands. Being the result of the combination of two bands, the NDVI partially corrects effects of atmospheric constituints and of radiometric and geometric distortions. The NDVI value varies from -1 and +1 . Negative values represent clouds, near zero values represent bare soil or soil without vegetation, and values greater than zero represent vegetation (Liu, 2006). The NDVI is represented by Equation 1.

$$
N D V I=(N I R-R) /(N I R+R)(\text { Equation 1) }
$$

Where:

NIR = reflectance of the vegetation in the near infrared band;

$\mathrm{R}=$ reflectance of the vegetation in the red band.

The NDVI was generated for each image and cropped according to the shapefile of the conservation unit, data coming from the state secretaries for the environment of Mato Grosso and Mato Grosso do Sul. The NDVI images were reclassified in six bands, according to the method of Andrade et al. (2012). With the intervals of pixels grouped into categories, it was possible to quantifty the percentage of areas per category. All procedures in this study were performed in the free GIS program QGIS 2.8 (QGIS Development Team, 2015).

\section{ANALYSES OF WILDFIRES AND DEFORESTATION}

The fire hotspots for the conservation units were obtained from the website of Brazil's National Institute for Space Research (Instituto Nacional de Pesquisas Espaciais - INPE),

Table 2. Date, orbit, and point of the Landsat satellite images in the analysis of the conservation units in the Pantanal wetlands.

\begin{tabular}{c|c}
\hline Orbit/Point & Dates of passage \\
\hline $227 / 72$ & $05 / 09 / 2000 ; 13 / 08 / 2003 ; 08 / 08 / 2007 ; 18 / 07 / 2011 ; 30 / 08 / 2015$ \\
\hline $227 / 73$ & $20 / 08 / 2000 ; 29 / 08 / 2003 ; 27 / 08 / 2007 ; 04 / 09 / 2011 ; 30 / 08 / 2015$ \\
\hline $226 / 72$ & $18 / 08 / 2000 ; 09 / 09 / 2003 ; 07 / 08 / 2007 ; 12 / 08 / 2011 ; 07 / 08 / 2015$ \\
\hline $226 / 73$ & $13 / 08 / 2000 ; 23 / 09 / 2003 ; 02 / 09 / 2007 ; 13 / 09 / 2011 ; 07 / 08 / 2015$ \\
\hline $226 / 74$ & $13 / 08 / 2000 ; 23 / 09 / 2003 ; 12 / 09 / 2007 ; 12 / 09 / 2011 ; 07 / 08 / 2015$ \\
\hline
\end{tabular}

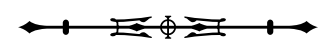


from the data bank of fire hotspots in protected areas (INPE, 2016a). The research was done per conservation unit in the four-month period before the date of the satellite images.

The analyses were necessary to understand if a drop in NDVI was due to low photosynthetic activity and biomass of the vegetation, large areas covered by water or due to suppression by wildfires or deforestation, since the two latter events should not happen in a conservation unit. Eventually, we could have missed to detect an occurred wildfire due to the chosen dates of the satellite images in the applied method.

With regard to forest clearing, the data INPE bank of the Project for the Monitoring of Deforestation (program PRODES) makes freely available data on areas with suppressed vegetation detected in conservation units and indigenous lands before 2014, without taking into account the date of their creation (INPE, 2016b).

\section{RESULTS}

The Taiamã Ecological Station had a predominance of NDVI values above 0.61 , which corresponds to an expressive amount of phytomass of Seasonal Semi-deciduous Alluvial Forest, pioneer and secondary vegetation (Andrade et al., 2012). During the analysed period, we observed that after 2007 there was a reduction of NDVI values for the class 0.61-0.75. In counterpart, the class with values above 0.76 increased in the same period (Figure 2).
The enlargement of the protected area of the conservation unit in 2009 contributed to its conservation, since it allowed an increase of phytomass. Similar improvement was observed in the buffer zone, where we did not observe human activities causing pressure on the landscape, complying with Resolution 428 of CONAMA (Brasil, 2010). We observed that the classes with interval below 0.60 correspond to less than 10\% of pixels at Taiamã Ecological Station and its buffer zone. These classes reached $13.24 \%$ in 2007, as well as the indices, the absence of fire hotspots in the area shows that the Estação Ecológica Taiamã is achieving protection of its biodiversity.

In the Encontro das Águas State Park we observed an increase in NDVI, and that after its creation, in 2004, there was an increase of ca. $50 \%$ of more phytomass, i.e., forest formations, and buffer zones presented the same change (Figure 3). Evaluating records of fire hotspots in this conservation unit for the considered period, only one fire spot was detected, on 29 September 2015, that probably slightly influenced the NDVI. We point out that $94 \%$ of pixels of NDVI in 2015 stayed within the two highest classes, and the class above 0.76 encompassed $50.6 \%$ of the pixels. Compared with 2003, one year before the creation of the park, such value totaled only $66.24 \%$, and only $0.61 \%$ represented the class with highest index, i.e., there was an increase of 33\% in the highest phytomass classes.

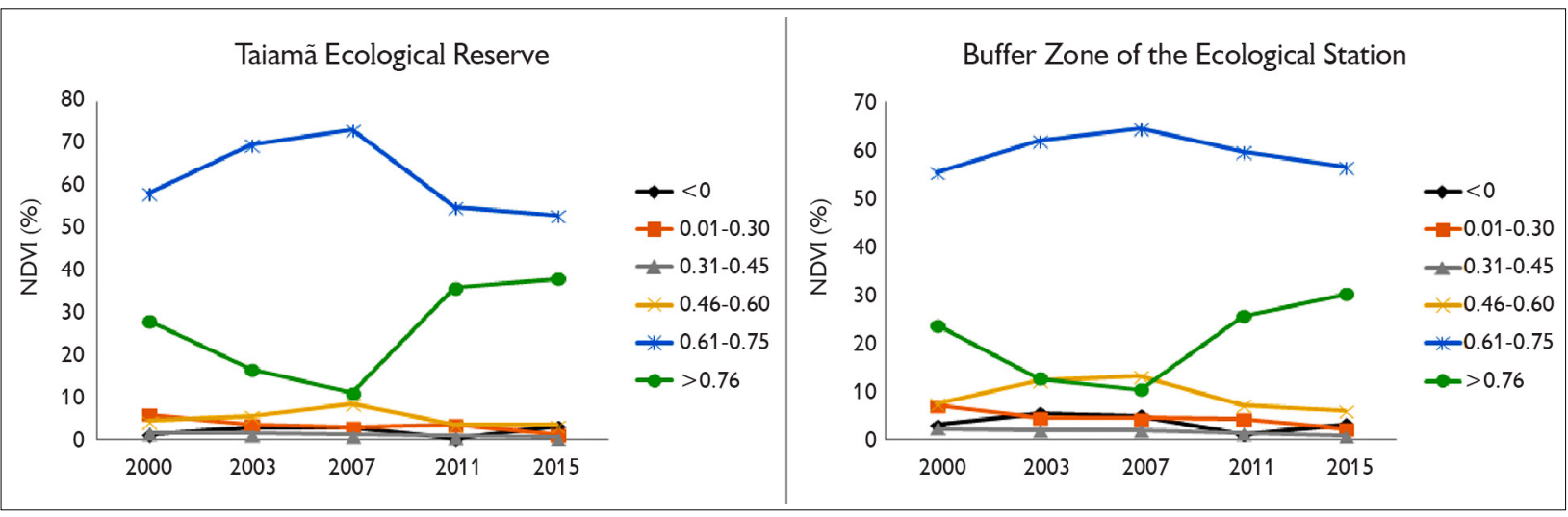

Figure 2. Evolution of NDVI values in percentage in the Taiamã Ecological Station (left) and its 3 km buffer zone 3 (right), in the Pantanal.

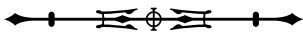




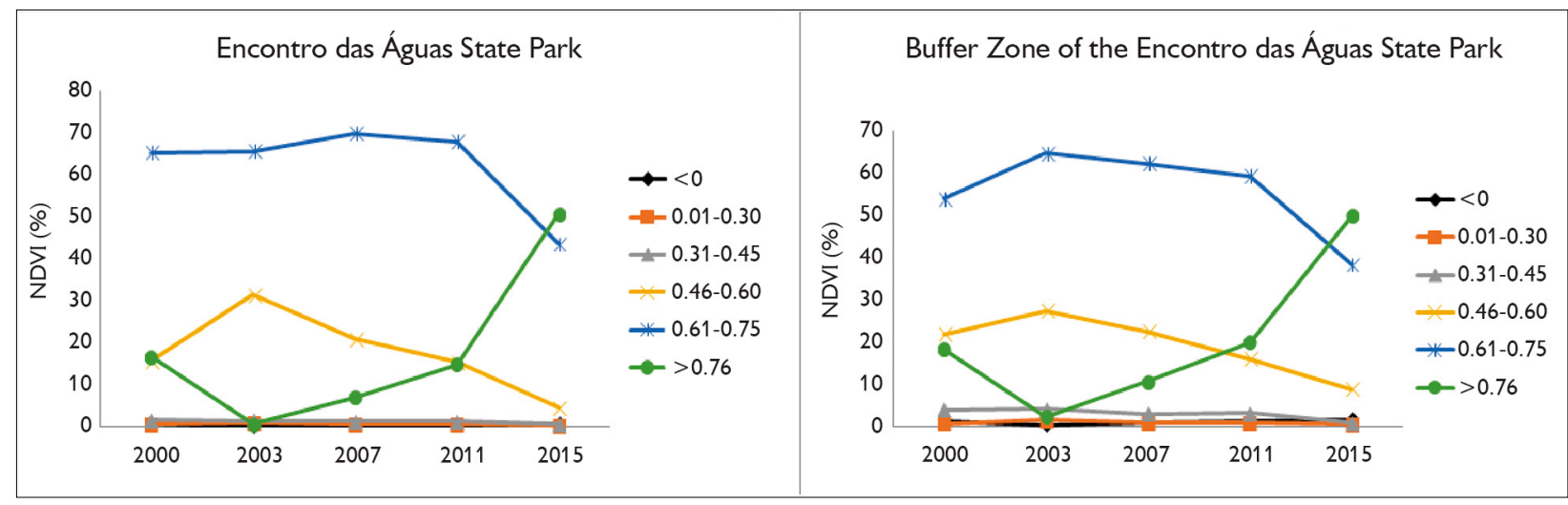

Figure 3. Evolution of NDVI values in percentage in the Encontro das Águas State Park (left) and its 3 km buffer zone (right), in the Pantanal.

The Pantanal of Rio Negro State Park, the only conservation unit of the Pantanal in Mato Grosso do Sul, presented an expressive increase in the range of 0.31 to 0.45 of NDVI, that means low phytomass, representing areas of grasslands, in the years from 2000 to 2007 , reaching ca. 50\% of the conservation unit's area in 2007 (Figure 4). The classes above 0.46 were reduced in 2007, probably due to the number of fire hotspots inside the unit detected by the satellite AQUA_M-T. In August and September, we verified 36 fire spots inside the park (INPE, 2016a) (Figure 4). In 2011 that number dropped to two spots and in 2015 two fire hotspots were also recorded. This scenario changed after 2007 with an increase of some classes of NDVI, such as 0.61-0.75. The buffer zone underwent the same process in 2015 when the predominant classes were those with NDVI values above 0.46 .

In the Guirá State Park, the NDVI range of 0.460.60 represented 28\% in 2000, but in 2011 and 2015 this value increased to $49 \%$ and $60 \%$, respectively. We observed that the phytomass increased after the creation of the park, but before that, in 2000, ca. $39 \%$ of the area had low NDVI (range of 0.01-0.30), compared with the year 2003 when 46,8\% of the area already had NDVI in the class 0.31-0.45. We observed that the greatest gain in phytomass occurred in the class between 0.46 and 0.60 , indicating denser formations and with higher photosynthetic activity, totaling $60 \%$ of the Guirá State Park in 2015, and similarly for the buffer zone (Figure 5). Regarding fire hotspots, in the four months

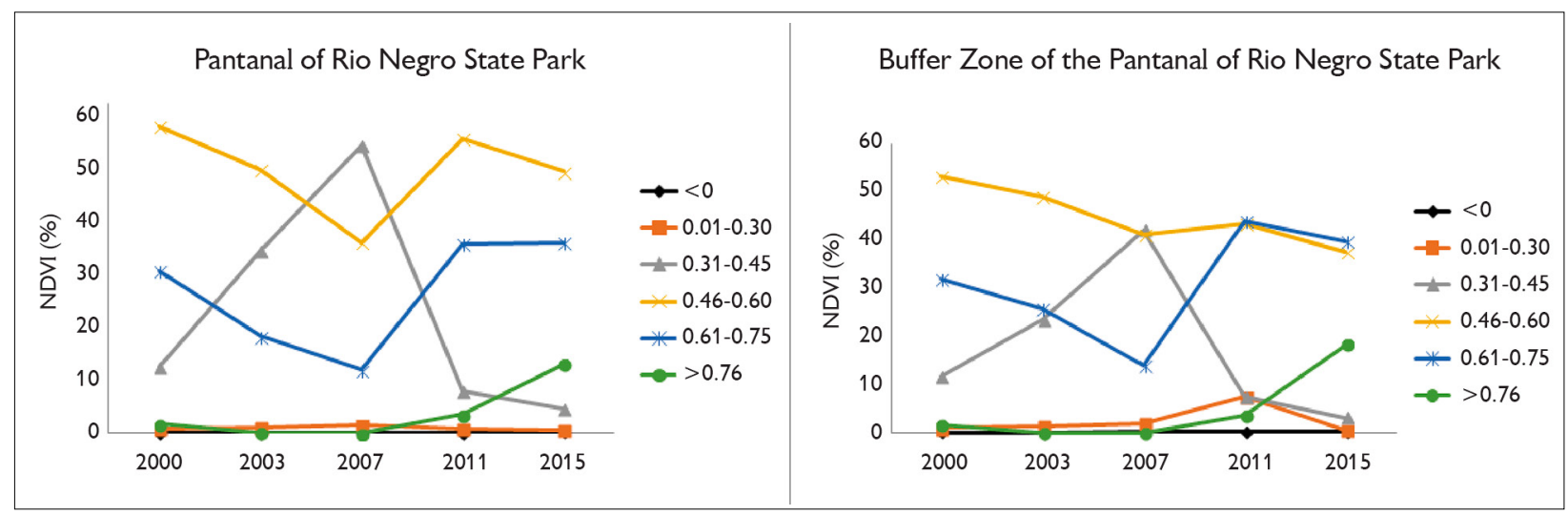

Figure 4. Evolution of NDVI values in percentage in the Pantanal of Rio Negro State Park (left) and its 3 km buffer zone (right), in the Pantanal.

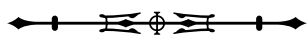


prior to each image we verified a fire spot in July 2007 and another in 2015.

The Pantanal Matogrossense National Park is the largest full protection area in the Pantanal. We observed that the NDVI values lower than 0 and 0.01 0.3 that represent the absence of vegetation, in this area representing the water bodies and swamps, had higher representativity than $10 \%$. The range of NDVI values $>$ 0.76 changed from 3,5\% of the area in 2000 to $20 \%$ in 2015, and in its buffer zone the same category grew from 5\% to 25\% (Figure 6). In this national park no fire hotspots were recorded in the analysed period.

Regarding deforestation, PRODES data showed that no vegetation supression was recorded in the Pantanal
Matogrossense National Park, the Taiamã Ecological Station, the Guirá State Park, and the Pantanal of Rio Negro State Park. Nevertheless, in the Encontro das Águas State Park we detected the clearing of 1.7 ha prior to its creation, but vegetation suppression stopped thereafter (INPE, 2016b).

\section{DISCUSSION}

Analyses carried out by means of Landsat vegetation indices are strategic for the management of conservation units and for permitting a consistent diagnosis of land cover in terms of vegetation biomass and cover percentage. The difference of reflectance provided by different wave lenghts on distinct land covers makes this type of analysis

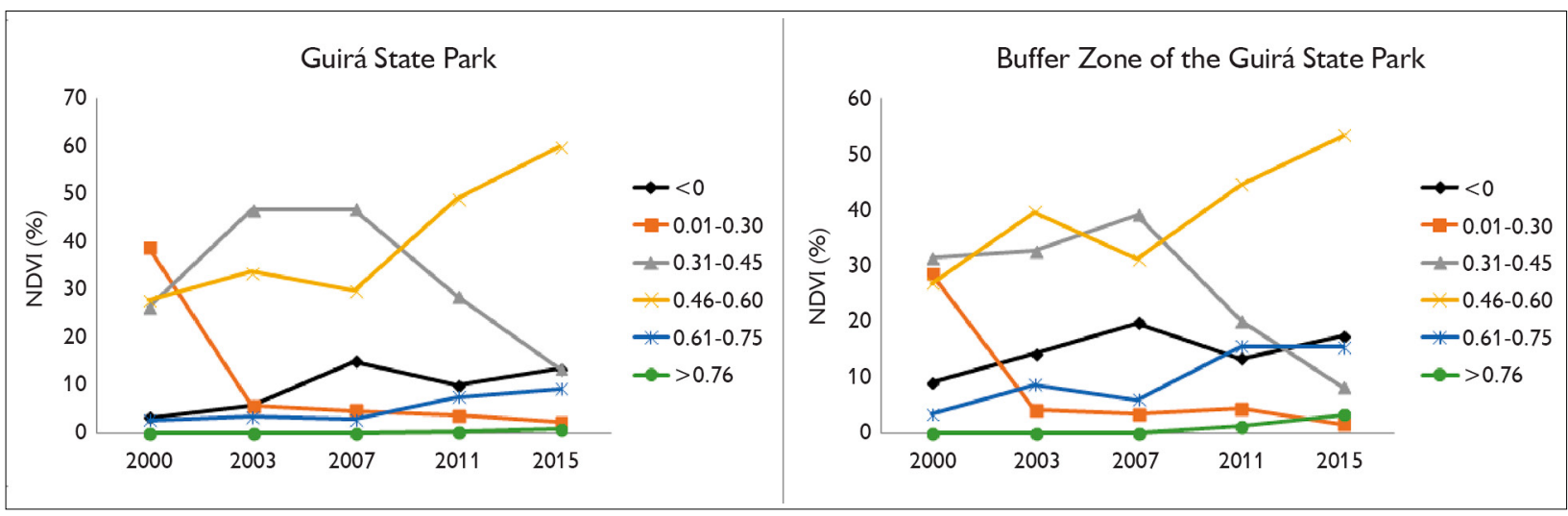

Figure 5. Evolution of NDVI classes in percentage of Guirá State Park (left) and its 3 km buffer zone (right), in the Pantanal.

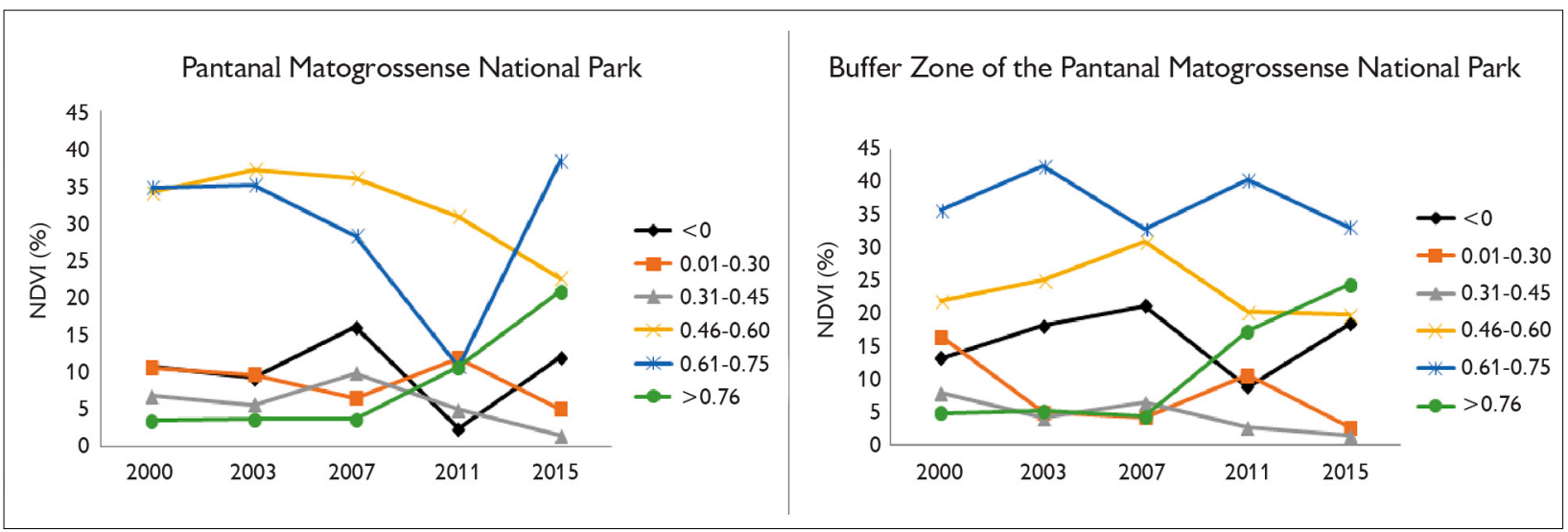

Figure 6. Evolution of NDVI classes in percentage of the Pantanal Matogrossense National Park (left) and its 3 km buffer zone (right), in the Pantanal.

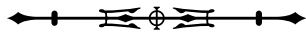


strategic since the procedure is relatively simplified when compared with other image processing routines. Some authors make use of the reclassification of indices for mapping land cover and calculation of areas (Rosendo \& Rosa, 2008; Santos \& Aquino, 2015; Peres et al., 2016).

We highlight the importance of satellite images in obtaining environmental data in wetlands (Schwerdtfeger et al., 2015). Our work corroborates the viability and effectiveness of the use of surface reflectance in Landsat images to generate and evaluate the vegetation in and around full protection conservation units of the Pantanal.

We observed high NDVI values on the margins of the Taiamã Ecological Station, that demonstrates an increase in vegetation biomass occurred inside the conservation unit, as well as in the buffer zone. The headquarters of this ecological station is near a small hill, called Taiamã Island, because it is surrounded by two branches of the Paraguay River and a wet floodplain, so it is rather safe from wildfires except in very dry years. Concerning the Encontro das Águas State Park, an increase in phytomass was noticeable after the creation of the state park, as well as in its buffer zone.

Regarding the Pantanal of Rio Negro State Park, an expressive increase of NDVI was observed in the range from 0.31 to 0.45 , in the period from 2000 to 2007, that can be atributted to cultivation (pasture), cattle ranching, and other human activities, as verified by Andrade et al. (2012). In relation to grazing, we can take into account that it occurred sporatically, due to cattle invasions through damaged fences, but to verify the real cause of the reduction of NDVI values, this should be checked with field data and mainly with the available management structure of the state park, in terms of staffing, training, vehicles, and infrastructure. Moreover, it possible that some of the fire hotspots verified inside this park may have been natural, since wildfires started by lightning are frequent in the region, or could spread from afar. The vegetation in this state park is cerrado woodland (partly cleared for pastures in the past but now in regeneration to woods), palm woodland, seasonally flooded grasslands, and riparian type forest, all of which are very fire prone, particularly ungrazed grasslands, and ponds. As observed by author AP in 2007, fire swept through the whole park.

\section{CONCLUSIONS}

Landsat satellite images freely available on the USGS website facilitate planing and environmental monitoring of conservation units, giving support to decision making about investments in environmental management of protected areas.

This work has the potential to facilitate for managers and proffessionals a basic technical understanding of remote sensing to produce quickly routine information on the conservation status of areas under their care that can be useful in the Pantanal, considering the peculiar characteristics of these protected areas such as their difficult access and distance from cities.

The data show that most conservation units have a high index of plant biomass, and no fire hotspots were verified, except one locus where surveillance needs to be intensified.

Our work shows the viability and effectiveness of surface reflectance from Landsat images provided by LEDAPS and L8SR to generate and evaluate the vegetation biomass within protected areas and in their buffer zones of the Pantanal.

\section{ACKNOWLEDGMENTS}

The authors thank the Brazilian agencies Coordenação de Aperfeiçoamento de Pessoal de Nível Superior (CAPES) and Fundação de Apoio ao Desenvolvimento do Ensino, Ciência e Tecnologia do Estado de Mato Grosso do Sul (FUNDECT) for scholarships to CSM, and the Conselho Nacional de Desenvolvimento Científico e Tecnológico (CNPq) for research productivity grants to $\mathrm{ACPF}, \mathrm{AP}$, and NMS.

\section{REFERENCES}

ANDRADE, R. G., G. C. SEDIYAMA, A. R. PAZ, P. L. LIMA \& A. G. FACCO, 2012. Geotechnologies applied to the assessment of biophysical parameters of the Pantanal biome. Pesquisa Agropecuária Brasileira 47(9): 1227-1234. DOI: <http://dx.doi. org/10.1590/S0100-204X2012000900007>. 
BRASIL, 2000. Lei n. 9.985, de 18 de julho de 2000. Regulamenta o art. 225, § 1o, incisos I, II, III e VII da Constituição Federal, institui - Sistema Nacional de Unidades de Conservação da Natureza e dá outras providências. Diário Oficial da União, 19 julho 2000. Avaiable at: <http://www.planalto.gov.br/ccivil_03/leis/L9985. htm>. Accessed on: April 05, 2016.

BRASIL, 2010. Resolução n 428, de 17 de dezembro de 2010. Dispõe, no âmbito do licenciamento ambiental, sobre a autorização do órgão responsável pela administração da Unidade de Conservação (UC), de que trata o $\S 3^{\circ}$ do artigo 36 da Lei no 9.985 de 18 de julho de 2000, bem como sobre a ciência do órgão responsável pela administração da UC no caso de licenciamento ambiental de empreendimentos não sujeitos a EIA-RIMA e dá outras providências. Diário Oficial da União, 20 dezembro 2010. Avaiable at: <http:// www.mma.gov.br/port/conama/legiabre. cfm?codlegi $=641>$. Accessed on: April 05, 2016.

HUETE, A., K. DIDAN, T. MIURA, E. P. RODRIGUEZ, X. GAO \& L. G. FERREIRA, 2002. Overview of the radiometric and biophysical performance of the MODIS vegetation indices. Remote Sensing of Environment 83(1-2): 195-213. DOI: <http://doi:10.1016/S00344257(02)00096-2>.

INSTITUTO NACIONAL DE PESQUISAS ESPACIAIS (INPE), 2016a. Banco de dados de queimadas. Available at: <https:// prodwww-queimadas.dgi.inpe.br/bdqueimadas/>. Accessed on: July 11, 2016.

INSTITUTO NACIONAL DE PESQUISAS ESPACIAIS (INPE), 2016b. Desmatamento em Unidades de Conservação, PRODES. Available at: <http://www.dpi.inpe.br/prodesdigital/prodesuc.php>. Accessed on: July 19, 2016.

LIU, W. T. H., 2006. Aplicações de sensoriamento remoto. Ed. UNIDERP, Campo Grande.

MASEK, J. G., E. F. VERMOTE, N. E. SALEOUS, R. WOLFE, F. G. HALL, K. F. HUEMMRICH, F. GAO, J. KUTLER \& T. K. LIM, 2006. A Landsat surface reflectance dataset for North America, 1990-2000. IEEE Geoscience and Remote Sensing Letters 3(1): 68-72. DOI: <https://doi.org/10.1109/LGRS.2005.857030>.

MINISTÉRIO DO MEIO AMBIENTE (MMA), 2014. BiomasPantanal. Available at: <http://www.mma.gov.br/biomas/pantanal >. Accessed on: July 20, 2014.

NAGENDRA, H., R. LUCAS, J. P. HONRADO, R. H. G. JONGMAN, C. TARANTINO, M. ADAMO \& P. MAIROTA, 2013. Remote sensing for conservation monitoring: assessing protected areas, habitat extent, habitat condition, species diversity, and threats. Ecological Indicators 33: 45-59. DOI: <https://doi.org/10.1016/j. ecolind.2012.09.014>.

NELSON, A. \& K. M. CHOMITZ, 2011. Effectiveness of strict vs. multiple use protected areas in reducing tropical forest fires: a global analysis using matching methods. PLoS ONE 6(8): e22722. DOI: $<$ https://doi.org/10.1371/journal.pone.0022722>.
PERES, P. N., C. L. MIOTO, J. MARCATO JUNIOR \& A. C. PARANHOS FILHO, 2016. Variação da cobertura do solo no Pantanal de 2000 a 2015 por sensoriamento remoto com software e dados gratuitos. Anuário do Instituto de Geociências 39(2): 116-123. DOI: <http://dx.doi.org/10.11137/2016_2_116_123>.

PRABAKARAN, C., C. P. SINGH, S. PANIGRAHY \& J. S. PARIHAR, 2013. Retrieval of forest phenological parameters from remote sensingbased NDVI time-series data. Current Science 105(6): 795-802.

QGIS DEVELOPMENT TEAM, 2015. QGIS ver. 2.8. Available at: <http://www.qgis.org/pt BR/site/index.html>. Accessed on: February 05, 2016.

ROSENDO, J. S. \& R. ROSA, 2008. Mapeamento do uso da terra e cobertura vegetal a partir do índice de vegetação NDVI. Avaiable at: <http://observatoriogeograficoamericalatina.org.mx/ egal12/Nuevastecnologias/Teledeteccion/16.pdf $>$. Accessed on: March 12, 2016.

ROUSE, J. W., R. H. HAAS, J. A. SCHELL \& D. W. DEEERING, 1973. Monitoring vegetation systems in the Great Plains with ERTS (Earth Resources Technology Satellite). Annals of the ERTS (Earth Resources Technology Satellite) Symposium 3: 309-317.

SAITO, N. S., M. A. MOREIRA, A. R. SANTOS, F. C. EUGENIO \& A. C. FIGUEIREDO, 2016. Geotecnologia e ecologia da paisagem no monitoramento da fragmentação florestal. Floresta e Ambiente 23(2): 201-210. DOI: <http://dx.doi.org/10.1590/2179-8087.119814>.

SANTOS, F. A. \& C. M. S. AQUINO, 2015. Análise da dinâmica do Índice de Vegetação por Diferença Normalizada (NDVI), dos aspectos econômicos e suas relações com a desertificação/degradação ambiental em Castelo do Piauí, Piauí, Brasil. Revista Electrónica de Investigação e Desenvolvimento 4: 23-32.

SCHWERDTFEGER, J., S. W. G. SILVEIRA, P. ZEILHOFER \& M. WEILER, 2015. Coupled ground- and space-based assessment of regional inundation dynamics to assess impact of local and upstream changes on evaporation in tropical wetlands. Remote Sensing 7(8): 9769-9795. DOI: <http://dx.doi.org/10.3390/rs70809769>.

SILVA, N. M., A. M. BATISTELLA, A. M. M. COELHO \& V. L. N. KUROYANAGI, 2009. Monitoramento do desmatamento e de focos de calor na zona de amortecimento da Estação Ecológica Estadual do Rio Ronuro, Nova Ubiratã, Mato Grosso. Engenharia Ambiental Espírito Santo do Pinhal 6(2): 484-491.

TIMKO, J. A. \& J. L. INNES, 2009. Evaluating ecological integrity in national parks: case studies from Canada and South Africa. Biological Conservation 142(3): 676-688. DOI: <http://dx.doi.org/10.1016/j. biocon.2008.11.022>.

UNITED STATES GEOLOGICAL SURVEY (USGS), 2013. Product guide: Landsat climate data record (CDR) surface reflectance. Department of Interior U.S. Geological Survey. Avaiable at: < http:// landsat.usgs.gov/documents/cdr_sr_product_guide.pdf > . Accessed on: February 21, 2016.

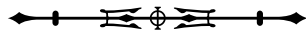


UNITED STATES GEOLOGICAL SURVEY (USGS), 2016. Product guide: Provisional Landsat 8 surface reflectance product. Department of Interior U.S. Geological Survey. Avaiable at: < http://landsat.usgs. gov/documents/provisional_18sr_product_guide.pdf $>$. Accessed on: March 7, 2016.

UNITED STATES GEOLOGICAL SURVEY (USGS), [s.d.]. Earth Explorer. Avaiable at: <http://earthexplorer.usgs.gov/> . Accessed on: February 21, 2016.

VERMOTE, E. F., D. TANRÉ, J. L. DEUZÉ, M. HERMAN \& J. J. MORCRETTE, 1997. Second simulation of the satellite signal in the solar spectrum, 6s: an overview. IEEE Transactions on Geoscience and Remote Sensing 35(3): 675-686.
WILLIS, K. S., 2015. Remote sensing change detection for ecological monitoring in United States protected areas. Biological Conservation 182: 233-242. DOI: <http://dx.doi.org/10.1016/j. biocon.2014.12.006>.

XIE, Y., Z. SHA \& M. YU, 2008. Remote sensing imagery in vegetation mapping: a review. Journal of Plant Ecology 1(1): 9-23. DOI: <https://doi.org/10.1093/jpe/rtm005>. 